Paper presented at the annual APSA Convention, September 2021

Author: Lelde Luik, University of Tartu

Estonia

\title{
Hannah Arendt and Representative Democracy: Authority as a Non- Foundational Category
}

\section{Introduction}

The crisis of representative democracy has been a long-lauded problem in the literature of political science, but only more recently, by challenging developments in the presumably stable Western democracies, it has entered a wider public consciousness. While the concern about dropping rates of voter turnout, lowering membership in civic and political organizations and distrust to representative institutions has been voiced among experts for a long time ${ }^{1}$, the conception of Western liberal democracy was never seriously called into doubt. However, during the recent years, in a clear connection with the events in the Western democracies and beyond, there has been a surge of literature that tries to address the question whether democracy is still viable, and if so - how it can compete with its alternatives ${ }^{2}$.

Thus, the meaning of representative democracy has become more prominent as a theoretical issue, posing the more fundamental questions of how democracy should work, and more specifically - how its institutions should reconnect with citizens, their constituents. Democratic theory has largely addressed this question with underlining the opportunities of deliberative and participatory democracy, detailing the way how traditional representative

${ }^{1}$ Russell J. Dalton, Democratic Challenges, Democratic Choices: The Erosion of Political Support in Advanced Industrial Democracies: The Erosion of Political Support in Advanced Industrial Democracies (Oxford University Press, UK, 2004); Pippa Norris, Democratic Deficit: Critical Citizens Revisited (Cambridge University Press, 2011).

${ }^{2}$ Roberto Stefan Foa and Yascha Mounk, "The Democratic Disconnect," Journal of Democracy 27, no. 3 (2016): 5-17, https://doi.org/10.1353/jod.2016.0049; Steven Levitsky and Daniel Ziblatt, How Democracies Die (Crown, 2018); David Runciman, How Democracy Ends (Profile Books, 2018). 
institutions could be supplemented or even substituted by the direct forms of democracy. Political science meanwhile has focused on the procedural mechanisms of representative democracy, with the less or more implicit assumption that those are 'rules of the game' that ultimately guarantee the satisfaction of citizens with their political institutions. Though the normative value of representative democracy is not undertheorized, in the context of the present democratic crisis there haven't been many attempts to formulate why representative democracy would be as valuable as direct and deliberative models of democracy. Along the shift in the underlying consensus in many established democracies about the meaning of such notions as 'freedom' and 'equality', the self-evident justification of representative democracy has become to waver. Yet, the issue is not simply about uncovering grounds for political rule, but about the role of specifically representative features of democracy in this process.

Several authors have outlined the specific role of political representation through what has been termed as the 'representative' or 'constructivist' turn in democratic theory ${ }^{3}$. The representative democracy, in fact, is argued to be a tautology ${ }^{4}$. Representation - and by implication representative institutions - are argued to take a greater than merely an intermediary function. The argument is that social preferences, interests and identities are formed during the political processes, in the interaction between political institutions and citizens, not merely transferred from a pre-political field. However, there is also a broader epistemological dimension to representation that ties with the non-foundationalist political philosophy ${ }^{5}$. The anti-essentialist perspective argues about the importance of keeping the meaning of 'the people' open as opposed to identifying it with any given political agent, and views representative institutions as the key symbolic obstacle for keeping the place of power 'empty'6.

The problem that constructivist approaches on representation have paid less attention to is the relationship between an authority and a democratic rule, and to address the gap between citizens and representative democracy, which forms the crux of the present crisis.

${ }^{3}$ Mónica Brito Vieira, ed., Reclaiming Representation: Contemporary Advances in the Theory of Political Representation (New York: Routledge, 2017), https://doi.org/10.4324/9781315681696; Lisa Disch, Mathijs van de Sande, and Nadia Urbinati, eds., The Constructivist Turn in Political Representation (Edinburgh University Press, 2019), https://doi.org/10.3366/edinburgh/9781474442602.001.0001.

${ }^{4}$ Sofia Näsström, "Representative Democracy as Tautology: Ankersmit and Lefort on Representation," European Journal of Political Theory 5, no. 3 (July 2006): 321-42, https://doi.org/10.1177/1474885106064664.

${ }_{5}^{5}$ Oliver Marchart, Post-Foundational Political Thought: Political Difference in Nancy, Lefort, Badiou and Laclau, Taking on the Political (Edinburgh: Edinburgh University press, 2007); Lasse Thomassen, "Poststructuralism and Representation," Political Studies Review 15, no. 4 (November 2017): 539-50, https://doi.org/10.1177/1478929917712932.

${ }^{6}$ Claude Lefort, Democracy and Political Theory, trans. David Macey, vol. 225 (Cambridge: Polity Press, 1988). 
Though these approaches deem to avoid polarity between the people and the government, in practical terms politicians are the privileged agents by becoming the focal points of representation ${ }^{7}$. The question is how we can be sure that 'the people' really do rule, while the institutions act in their name ${ }^{8}$ ? How do we account for a divergence between the popular ideal of democracy as a self-rule of the people and the reality of bureaucratic, hierarchical political authority?

My paper addresses this topic by focusing on the concept of authority. It draws on the non-foundationalist and constructivist premises but seeks to expand it by engaging author that it not often considered in this context - Hannah Arendt. Connections between Arendt's work and other non-foundationalist, radical democratic authors are well noted, however, she is not an obvious choice to reflect on authority and representative democracy. Generally, Arendt is regarded as critical or contradictive in her evaluation of representative democracy, considering the importance she places on the action by citizens themselves ${ }^{9}$. Yet Arendt is also a non-foundationalist and her work does not neatly fit with any of the existing democracy models. Arendt's work connects with those radical democratic and postfoundationalist perspectives that argue against attempts to place politics on an objective, supposedly universal grounds. Several scholars have warned that Arendt's work does not lend itself for a theory and model building that can then be applied for political analysis Arendt is known to argue about understanding politics 'in its own terms ${ }^{10}$. In the paper I explore the implications and possibilities that Arendtian perspective brings to understanding authority in modern representative democracies.

The plan for the paper is the following: I will first outline the existing readings of Arendt's notion of authority and the way it has been connected with theorizing representative democracy. I will then follow with non-foundationalist take on Arendt as theorist of democracy and restate Arendt's framework of action to situate her concept of authority. Finally, I will argue how the category of authority is relevant for the analysing problems of representative democracy.

${ }^{7}$ Sofia Näsström, "Where Is the Representative Turn Going?," European Journal of Political Theory 10, no. 4 (October 2011): 501-10, https://doi.org/10.1177/1474885111417783.

${ }^{8}$ Margaret Canovan, The People, 1st edition (Cambridge ; Malden, MA: Polity, 2005).

9 George Kateb, "Arendt and Representative Democracy," 2021, 41; Margaret Canovan, "The Contradictions of Hannah Arendt's Political Thought," Political Theory 6, no. 1 (February 1, 1978): 5-26, https://doi.org/10.1177/009059177800600102; Andreas Kalyvas, Democracy and the Politics of the Extraordinary: Max Weber, Carl Schmitt, and Hannah Arendt (Cambridge University Press, 2008).

${ }^{10}$ Lucy Cane, "Hannah Arendt on the Principles of Political Action," European Journal of Political Theory 14, no. 1 (January 2015): 55-75, https://doi.org/10.1177/1474885114523939. 


\section{Arendt as a Theorist of Authority}

There are three definitions that appear in relation to authority in Arendt's works. First of all, there is presumably the most known - the hierarchical structure of power, which is characterized by the obedience, instrumentality and rationality ${ }^{11}$. This form of authority, which Arendt sees as dominating both the Western political history and thought, is contrasted with Arendt's notion of power as rooted in equality and its exercise as a 'unreliable, temporary connection of wills ${ }^{12}$. The contrast that Arendt's conception of power presents to all traditional ideas of political theory - for instance, Arendt rejects sovereignty as a central political concept ${ }^{13}$ - understandably complicates her engagement with most democratic theories. As I will discuss below, much scholarship in this direction has attempted to find a workable, practical model of Arendt's notion of power in democratic politics or argued against it, invoking the accusations of elitism and utopianism ${ }^{14}$. The conception of politics as a meeting between equal citizens that use persuasion and argument, not command or obedience; the notion of action in the public space that is contrasted to automatic, ordinary day-to-day lives, in effect contrasting freedom and servitude, are, without doubt, crucial parts of Arendtian framework. Yet it is quite clear that Arendt has discussed concept of authority that fits in this framework - though its full implications are not always detailed in her work.

In the essay 'What is authority?' Arendt deals with idea of authority that 'implies an obedience in which men retain their freedom, ${ }^{, 15}$ and which both parties recognize as legitimate, neither because one has persuaded other, or has power over other. This is the authority whose beginnings Arendt traces to Plato and Roman Empire and which she sees restored to some degree in its authentic form through the American revolution and its constitution making in $18^{\text {th }}$ century. Finally, the third form of authority is closely related to the previous, in Arendt's view more legitimate conception, but I distinguish it because it has less immediate association with the empirical examples. It is what Arendt defines as the dimension of depth of politics, in contrast to the more temporal exercise of power here-and-

\footnotetext{
${ }^{11}$ Hannah Arendt, Between Past and Future: Eight Exercises in Political Thought (Harmondsworth: Penguin Books, 2006).

${ }^{12}$ Hannah Arendt, The Human Condition, 2nd ed (Chicago: University of Chicago Press, 1998).

${ }^{13}$ Arendt, Between Past and Future.

${ }^{14}$ Canovan, "The Contradictions of Hannah Arendt's Political Thought."

15 Arendt, Between Past and Future, 106.
} 
now. This means the "worldy permanence and reliability"16, and durability of a human community and its life, which is as important to Arendt as the unpredictability and unexpectedness of political action she is more often - and rightly - associated with. While these last two views on authority have received substantial attention in the scholarship, there remain important gaps in how they been interpreted in the context of representative democracy.

The opposition between authority as a vertical hierarchy versus the notion of power as an exercise of equality has informed many accounts of Arendt's attitude of representative democracy. George Kateb in an influential article argued that Arendt views representative democracy as a 'system of mass passivity' that prohibits citizens' direct participation in government's affairs and thus stunts authentic political action ${ }^{17}$. Kateb's main objection to Arendt is her supposed disdain of day-to-day economic, social, and other 'lesser' matters that are considered to be too self-involved to be included in the political sphere, which should draw on more elevated, impartial views on worldly affairs, the 'worldy impartiality' 18 as Kateb defines. Margaret Canovan also views Arendt's attitude towards masses and mass issues as elitist and even utopian: the lifestyle and values Arendt envisions as democratic are more suitable for few than for many, and enforces the same elite selection that her deplored representative mode ${ }^{19}$. Canovan wonders how this neglect of masses and their real concerns is compatible with Arendt's focus on new beginnings - such as in the case of her support to uprising and workers' councils in Hungary in 1956. Interpretations by Kateb and Canovan have very much influenced the proceeding accounts of Arendt's credentials as a democratic theorist. The responses mainly form two opposite directions: the first one exempts Arendt from typical representative model and presents her works as an alternative to it, while the second one argues that Arendt's notions can be integrated in the representative democracy and she has been misunderstood.

Thus, John F. Sitton argues against Arendt as a utopian theorist of participatory democracy, exemplified through her idea of council system ${ }^{20}$. Sitton repeats that for Arendt representative politics substitute possibility for a genuine action and thus exercise of freedom. More specifically, the impossibility to participate themselves in political decision-making doesn't give citizens an opportunity to form a personal opinion, and, instead of creating a

${ }^{16}$ Arendt, 95.

${ }^{17}$ Kateb, "Arendt and Representative Democracy."

${ }^{18}$ Kateb, 27.

${ }^{19}$ Canovan, "The Contradictions of Hannah Arendt's Political Thought."

${ }^{20}$ John F. Sitton, "Hannah Arendt's Argument for Council Democracy," Polity 20, no. 1 (September 1987): 80-100, https://doi.org/10.2307/3234938. 
space of public exchange, creates a reductive 'public opinion' ${ }^{21}$. Sitton rejects the assumption that Arendt limits debate on social issues and opens possibilities to study her work as providing a true alternative to the representative model. Jeffrey C. Isaac presents the council model not as an alternative to representative government, but as a possibility for citizens who are interested in it to develop a "meaningful citizenship" 22 . Taking into the consideration factor, noted by Arendt, that only a fraction of population will ever be motivated to act politically ${ }^{23}$, the councils provide an 'oasis' that gives an equal opportunity to participate, but does not make it a political baseline. Isaac argues that council model pluralizes political space and gives a chance to resist unjust, vertical authority of mass politics by creating 'pockets' where authority is shared by its members.

In a more recent literature, there are fewer attempts to place Arendt within a framework of representative democracy. James Muldoon re-emphasizes that for Arendt 'freedom means participation in government or it means nothing' ${ }^{24}$, and that any dilution of this principle makes her model meaningless. The debate about Arendt's conceptions is not whether they are anti-democratic and/or unrealistic, as democracy is much less identified with a single model of Western liberal democracy.

Arendt's political principles are opposed to liberal, administrative, party-led system, and seen as representing republican conception of democracy. Andreas Kalyvas distinguishes four main criticisms of democracy by Arendt: the rule of many over few, the lack of distinction between law and power, the dominance of economic issues in politics and the lack of procedures for forming public opinion ${ }^{25}$. The focus on common good that is opposed to the pursuit of selfish interests, taking part in the responsibility of governing and drawing on the living power of the community defines Arendt's brand of republicanism ${ }^{26}$. Its practical implementation does mean rejecting the parliament as the locus of decision-making - the idea of 'representing' action for Arendt is absurd - and placing councils as a law-making body ${ }^{27}$. The exercise of citizens' power through councils is combined with the stabilizing and impartial quality of the law and the institutions of judicial review - here Kalyvas engages

${ }^{21}$ Sitton, 84 .

${ }^{22}$ Jeffrey C. Isaac, "Oases in the Desert: Hannah Arendt on Democratic Politics," The American Political Science Review 88, no. 1 (1994): 156-68, https://doi.org/10.2307/2944888.

${ }^{23}$ Hannah Arendt, Crises of the Republic: Lying in Politics, Civil Disobedience on Violence, Thoughts on Politics, and Revolution (Harcourt Brace Jovanovich, 1972).

${ }^{24}$ James Muldoon, "Arendt's Revolutionary Constitutionalism: Between Constituent Power and Constitutional Form: Arendt's Revolutionary Constitutionalism: James Muldoon," Constellations 23, no. 4 (December 2016): 403, https://doi.org/10.1111/1467-8675.12179.

${ }^{25}$ Kalyvas, Democracy and the Politics of the Extraordinary.

${ }^{26}$ Kalyvas.

${ }^{27}$ Kalyvas. 
with Arendt's notion of authority as envisioned in the Roman and American revolution examples. Lisa Disch defines Arendt's council model as democratic republicanism, which is not only participatory, but also federative, representative and hierarchal ${ }^{28}$. This model rejects transposed or delegated representation and is based on self-authorization between its members ${ }^{29}$. Kalyvas and Disch exemplify how Arendt's concepts are reworked in alternative political models that problematize liberal conception as the sole interpretation of representative democracy. Representation is more than a procedural feature of the liberal democracy and thus not in a contradiction with Arendtian ideas.

The shifting focus in the scholarship makes Arendt less as an opponent of democracy as was hypothesized by Kateb and Canovan, but more a proponent of radical democracy that seeks to preserve the energy of the constituent power $^{30}$. The fact whether it is done in the framework of representative democracy is less important per se, though the modern parliamentary politics is not perceived as a place to do so successfully. The dimension where more recent accounts on Arendt are struggling are the potential application of her ideas to practical politics, and it concerns directly the conception of authority. Earlier the distinction between representative and direct democracy also made clear the distinction between traditional authority of representative government, of which Arendt is critical of, and the authority that is constituted by mutual obligations and trust among its members, as was propositioned by Sitton ${ }^{31}$. With less attempt to fit Arendt's notions in the existing framework of liberal democracy, the arrangements of authority also become less concrete. Kalyvas emphasizes the historical continuity dimension of Arendt's notion of authority and connects it with legal institutes and laws. He specifically mentions the Supreme Court and the debate or the augmentation - of the constitutional matters, invoking also Arendt's analysis of the American example ${ }^{32}$. However, the manner in which authority functions through the system of council democracy is not something Kalyvas directly discusses, leaving the relationship between the direct and temporary expression of power and the continuous, lasting effect of law open. Kalyvas is one of the few to highlight Arendt's dimensions of both present and depth of politics, but he doesn't go into a detail to address the complications of integrating

${ }^{28}$ Lisa Disch, "How Could Hannah Arendt Glorify the American Revolution and Revile the French? Placing On Revolution in the Historiography of the French and American Revolutions," European Journal of Political Theory 10, no. 3 (July 2011): 350-71, https://doi.org/10.1177/1474885111406389.

${ }^{29}$ Disch.

${ }^{30}$ Muldoon, "Arendt's Revolutionary Constitutionalism."

${ }^{31}$ Sitton, "Hannah Arendt's Argument for Council Democracy," 87.

${ }^{32}$ Kalyvas, Democracy and the Politics of the Extraordinary. 
both unexpectedness and durability others have pointed out ${ }^{33}$. Disch addresses the other dimension of authorization that concerns the creation of self-affirmed ties between its members, echoing Sitton's argument ${ }^{34}$. She raises question of how accountability and change can be ensured in the framework of self-authorization, which is the sole option, if Arendt's political concepts are taken seriously.

Arendt's categories thus have over time become more aligned with democracy in republican terms but remain ambiguous in their practical implementation. Furthermore, the traditional institutions of representative democracy, with the exception of courts, have a very little role assigned in the accounts on Arendtian democracy. This, in turn, complicates application of Arendt's thought to the events of contemporary democracies, which are very much composed by these same institutions. Considering Arendt's 'Amor mundi' ${ }^{35}$, it seems strange to invoke her political concepts in abstract theorizing of democratic models or only in relation to historical experiences.

\section{Arendt's non-foundationalist view on authority}

My perspective in formulating a way out of this conundrum is to return to the nonfoundationalist aspects of Arendt's thought in relation to democratic theory. The fact that Arendt is someone who understood the loss of definite source of authority as a defining feature of modernity is not new ${ }^{36}$. In fact, a lot of her work that is analysed for clues of a democratic template, can be seen as an discussion how to establish authority in a time where any such lasting and absolute foundations are lost ${ }^{37}$. This inquiry, which more often than not, has been based in a historical analysis does not mean that Arendt comes up with an identifiable model. Instead, she unearths categories and notions with which we can understand political events from the perspective of the loss of authority she defines and its appearance in the modern world. In this sense, the efforts to set out practical implementation of Arendtian democracy as a singular framework might not be the most helpful. As the following discussion will show, Arendt's non-foundationalist approach to authority does not

33 B. Honig, "Declarations of Independence: Arendt and Derrida on the Problem of Founding a Republic," American Political Science Review 85, no. 1 (March 1991): 97-113, https://doi.org/10.2307/1962880.

${ }^{34}$ Disch, "How Could Hannah Arendt Glorify the American Revolution and Revile the French?"

35 J. W. Bernauer, ed., Amor Mundi: Explorations in the Faith and Thought of Hannah Arendt, Martinus Nijhoff Philosophy Library (Springer Netherlands, 1987), https://doi.org/10.1007/978-94-009-3565-5.

${ }^{36}$ Honig, "Declarations of Independence."

${ }^{37}$ Honig. 
necessarily imply identifying institutes that would define its form but recognizing the meaning of worldly events in relation to its appearance.

Bonnie Honig traces the study of authority in "On revolution"' as both historical analysis of the constitution making in the U.S. and as an exercise of defining the features of modern authority ${ }^{38}$. Honing takes seriously Arendt's point about interrelatedness of power and authority ${ }^{39}$, which is one of the most challenging aspects for her readers due to their apparent contradiction. She solves it by reformulating the performative act of politics as a source for both - something which corresponds to Arendt's discussion of action in terms of its virtuosity not as the finished 'product' ${ }^{40}$. The American constitution making exemplifies this idea: the act of foundation becomes the source of authority, but it is alive while the citizens change and make it personal through their actions ${ }^{41}$. In this sense, deauthorization becomes the practice of authority ${ }^{42}$. As Honig writes, authority here is not about finding a source of stability, since excessive attachment to any foundation can turn into its reification, clearly rejected by Arendt. The form of authority that Honig, for instance, sees in the speech acts, does not refer to institutional arrangements or definitions, but to the activity that makes a certain principle of action visible.

To make this distinction clearer, it is valuable to revisit Arendt's concepts and the way she related them to action. Action itself is a central concept for Arendt's political theory that can be taken as a starting point to untangle its connections. The understand action it is important to see its opposite: the automatism and reification of 1 if $\mathrm{e}^{43}$. This dimension that Arendt also defines as labour ${ }^{44}$ is unescapable part of human lives on earth, which creates a framework, a background against which action can be recognized ${ }^{45}$. This is where enters freedom - capacity to break the cycles of repetition and start something new. Though individual has the will and judgement over the action they take, the freedom exists in the act that by itself has nothing to do with motive and goal of the doer ${ }^{46}$. Most importantly, because freedom is not possessed by individual, it exists through its appearance to and recognition by others ${ }^{47}$. Here finally enters the public space, a worldly place where freedom can be

\footnotetext{
${ }^{38}$ Honig.

${ }^{39}$ Hannah Arendt, On Revolution (Penguin, 2006), 155.

${ }^{40}$ Arendt, Between Past and Future, 164-65.

${ }^{41}$ Honig, "Declarations of Independence."

42 Honig.

${ }^{43}$ Arendt, Between Past and Future, 168.

${ }^{44}$ Arendt, The Human Condition.

${ }^{45}$ Arendt, Between Past and Future, 169.

46 Arendt, 152.

${ }^{47}$ Arendt, 156.
} 
manifested and where it can generate a genuine power through the association of individuals. Action, freedom and power are all faculties, another Arendtian term, which spring from the individual but acquire their realization in the public realm, in its plurality and worldliness.

In this perspective, authority can be seen faculty of a similar type; if freedom is the faculty of beginning ${ }^{48}$, then authority can be the faculty of remembering. Institutions for Arendt is a result of action, not of making - another notion that Arendt has connected with labour - the automatism and production ${ }^{49}$. The conservation and longevity that authority encompasses does not result from the fact that it establishes stability and rules - but because it is subject to continuous action in Arendtian sense. Yet it is not identical to freedom as the act of beginning or power as the union of many wills - it targets the remembrance and continuity of the world, and the life of the particular community. In this sense it can be seen as a faculty of remembering that I take to be the most universal dimension of authority from those Arendt has discussed. In her work, there appear several notions of authority that can be mutually exclusive. It is important to trace which of these notions Arendt uses to describe a historical-sociological context and which she situates as part of her normative framework of work, labour and action. Within this framework in the way I have described above, the most outstanding feature of authority is the continuity and preservation. In a true Arendtian fashion this has to be interrelated to power as a temporary and extraordinary moment, which is what creates its performative, non-foundationalist character.

Understanding authority in such non-foundationalist way opens its applicability to analysing developments in modern democracies and to not be caught up in the questions about direct presence and representation in politics. Thinking about authority does not necessarily mean grappling with institutions, hierarchies and mandates. The question is rather what the meaning of the events is we see in the world, meaning that we can establish with categories - such as those that Arendt provides. Lucy Cane shows an example of nonfoundationalist approach in using Arendt's work by focusing on her notion of principles ${ }^{50}$. Principles are another part of Arendt's framework of action that yield basis of moral and ethical evaluation of the exercise of freedom ${ }^{51}$. Cane correctly identifies the dimension of analysis that can be derived from Arendt's work, which, as also argued by Lisa Disch in an

\footnotetext{
${ }^{48}$ Arendt, Between Past and Future.

${ }^{49}$ Arendt, 153.

${ }^{50}$ Cane, "Hannah Arendt on the Principles of Political Action."

51 Cane.
} 
earlier article ${ }^{52}$, does not seek a vantage point outside of the social world, but invites its readers to think critically.

\section{Conclusion}

Hannah Arendt's work is neither utopian, nor enclosed in the past, and it is also not estranged to the current democratic processes. Arendt, who linked thinking with response to actual, world events, is more often than not alienated from the ability to respond to modern democracies and their failures - either due to her alleged elitism, the rejection of modernity, impracticality, and more. More critical perspectives engage Arendt by theorizing alternative models to liberal democracy, using her notions on action, public space and freedom. Her work definitely lends itself to such theorizing and Arendt herself has outlined an alternative model of council system, of which much has been made by other authors. Yet, as the paper has shown, the existing perspectives ignore a different conceptualization of politics that appear through her notion of authority.

In the paper I argue that Arendt's discussion of authority as well as concepts she relates with it, such as action, freedom and power, have not been fully exhausted in the value they can bring to theorizing representative democracy. While it is true that Arendt's works are difficult to transform into a systemic political theory, and that, indeed, it would go against her philosophical position on politics, her distinctions of political life create an important theoretical and methodological horizon.

In the light of increasingly complex relations between democratic constituencies and their governments, conceptualizing representative democracy should steer away from 'fixing' the authority in its traditional, hierarchical sense. The objective that Arendt's categories help to achieve is to keep in view both the immediate, unpredictable elements of human interaction through politics and the elements that make-up the world in which this interaction unfolds.

\footnotetext{
52 Lisa J. Disch, "More Truth than Fact: Storytelling as Critical Understanding in the Writings of Hannah Arendt," Political Theory 21, no. 4 (November 1993): 665-94, https://doi.org/10.1177/0090591793021004006.
} 
Bibliography

Arendt, Hannah. Between Past and Future: Eight Exercises in Political Thought. Harmondsworth: Penguin Books, 2006.

Crises of the Republic: Lying in Politics, Civil Disobedience on Violence, Thoughts on Politics, and Revolution. Harcourt Brace Jovanovich, 1972.

On Revolution. Penguin, 2006.

. The Human Condition. 2nd ed. Chicago: University of Chicago Press, 1998.

Bernauer, J. W., ed. Amor Mundi: Explorations in the Faith and Thought of Hannah Arendt. Martinus Nijhoff Philosophy Library. Springer Netherlands, 1987. https://doi.org/10.1007/978-94-009-3565-5.

Cane, Lucy. "Hannah Arendt on the Principles of Political Action." European Journal of Political Theory 14, no. 1 (January 2015): 55-75. https://doi.org/10.1177/1474885114523939.

Canovan, Margaret. "The Contradictions of Hannah Arendt's Political Thought." Political Theory 6, no. 1 (February 1, 1978): 5-26. https://doi.org/10.1177/009059177800600102.

- The People. 1st edition. Cambridge ; Malden, MA: Polity, 2005.

Dalton, Russell J. Democratic Challenges, Democratic Choices: The Erosion of Political Support in Advanced Industrial Democracies: The Erosion of Political Support in Advanced Industrial Democracies. Oxford University Press, UK, 2004.

Disch, Lisa. "How Could Hannah Arendt Glorify the American Revolution and Revile the French? Placing On Revolution in the Historiography of the French and American Revolutions." European Journal of Political Theory 10, no. 3 (July 2011): 350-71. https://doi.org/10.1177/1474885111406389.

Disch, Lisa J. "More Truth than Fact: Storytelling as Critical Understanding in the Writings of Hannah Arendt." Political Theory 21, no. 4 (November 1993): 665-94. https://doi.org/10.1177/0090591793021004006.

Disch, Lisa, Mathijs van de Sande, and Nadia Urbinati, eds. The Constructivist Turn in Political Representation. Edinburgh University Press, 2019. https://doi.org/10.3366/edinburgh/9781474442602.001.0001.

Foa, Roberto Stefan, and Yascha Mounk. "The Democratic Disconnect." Journal of Democracy 27, no. 3 (2016): 5-17. https://doi.org/10.1353/jod.2016.0049.

Honig, B. "Declarations of Independence: Arendt and Derrida on the Problem of Founding a Republic." American Political Science Review 85, no. 1 (March 1991): 97-113. https://doi.org/10.2307/1962880.

Isaac, Jeffrey C. "Oases in the Desert: Hannah Arendt on Democratic Politics." The American Political Science Review 88, no. 1 (1994): 156-68. https://doi.org/10.2307/2944888.

Kalyvas, Andreas. Democracy and the Politics of the Extraordinary: Max Weber, Carl Schmitt, and Hannah Arendt. Cambridge University Press, 2008.

Kateb, George. "Arendt and Representative Democracy," 2021, 41.

Lefort, Claude. Democracy and Political Theory. Translated by David Macey. Vol. 225. Cambridge: Polity Press, 1988.

Levitsky, Steven, and Daniel Ziblatt. How Democracies Die. Crown, 2018.

Marchart, Oliver. Post-Foundational Political Thought: Political Difference in Nancy, Lefort, Badiou and Laclau. Taking on the Political. Edinburgh: Edinburgh University press, 2007.

Muldoon, James. “Arendt's Revolutionary Constitutionalism: Between Constituent Power and Constitutional Form: Arendt's Revolutionary Constitutionalism: James 
Muldoon." Constellations 23, no. 4 (December 2016): 596-607. https://doi.org/10.1111/1467-8675.12179.

Näsström, Sofia. "Representative Democracy as Tautology: Ankersmit and Lefort on Representation.” European Journal of Political Theory 5, no. 3 (July 2006): 321-42. https://doi.org/10.1177/1474885106064664.

_. "Where Is the Representative Turn Going?" European Journal of Political Theory 10, no. 4 (October 2011): 501-10. https://doi.org/10.1177/1474885111417783.

Norris, Pippa. Democratic Deficit: Critical Citizens Revisited. Cambridge University Press, 2011.

Runciman, David. How Democracy Ends. Profile Books, 2018.

Sitton, John F. "Hannah Arendt's Argument for Council Democracy." Polity 20, no. 1 (September 1987): 80-100. https://doi.org/10.2307/3234938.

Thomassen, Lasse. "Poststructuralism and Representation." Political Studies Review 15, no. 4 (November 2017): 539-50. https://doi.org/10.1177/1478929917712932.

Vieira, Mónica Brito, ed. Reclaiming Representation: Contemporary Advances in the Theory of Political Representation. New York: Routledge, 2017. https://doi.org/10.4324/9781315681696. 